\title{
Creating COVID-19 Stigma by Referencing the Novel Coronavirus as the "Chinese virus" on Twitter: Quantitative Analysis of Social Media Data
}

Henna Budhwani, MPH, PhD; Ruoyan Sun, MHS, PhD

Department of Health Care Organization and Policy, School of Public Health, University of Alabama at Birmingham, Birmingham, AL, United States

\section{Corresponding Author:}

Henna Budhwani, MPH, PhD

Department of Health Care Organization and Policy

School of Public Health

University of Alabama at Birmingham

1720 University Blvd

RPHB \#330C

Birmingham, AL, 35294

United States

Phone: 12059757613

Email: budhwani@uab.edu

\section{Abstract}

Background: Stigma is the deleterious, structural force that devalues members of groups that hold undesirable characteristics. Since stigma is created and reinforced by society—through in-person and online social interactions-referencing the novel coronavirus as the "Chinese virus" or "China virus" has the potential to create and perpetuate stigma.

Objective: The aim of this study was to assess if there was an increase in the prevalence and frequency of the phrases "Chinese virus" and "China virus" on Twitter after the March 16, 2020, US presidential reference of this term.

Methods: Using the Sysomos software (Sysomos, Inc), we extracted tweets from the United States using a list of keywords that were derivatives of "Chinese virus." We compared tweets at the national and state levels posted between March 9 and March 15 (preperiod) with those posted between March 19 and March 25 (postperiod). We used Stata 16 (StataCorp) for quantitative analysis, and Python (Python Software Foundation) to plot a state-level heat map.

Results: A total of 16,535 "Chinese virus" or "China virus" tweets were identified in the preperiod, and 177,327 tweets were identified in the postperiod, illustrating a nearly ten-fold increase at the national level. All 50 states witnessed an increase in the number of tweets exclusively mentioning "Chinese virus" or "China virus" instead of coronavirus disease (COVID-19) or coronavirus. On average, 0.38 tweets referencing "Chinese virus" or "China virus" were posted per 10,000 people at the state level in the preperiod, and 4.08 of these stigmatizing tweets were posted in the postperiod, also indicating a ten-fold increase. The 5 states with the highest number of postperiod "Chinese virus" tweets were Pennsylvania $(n=5249)$, New York $(n=11,754)$, Florida $(n=13,070)$, Texas $(n=14,861)$, and California $(n=19,442)$. Adjusting for population size, the 5 states with the highest prevalence of postperiod "Chinese virus" tweets were Arizona (5.85), New York (6.04), Florida (6.09), Nevada (7.72), and Wyoming (8.76). The 5 states with the largest increase in pre- to postperiod "Chinese virus" tweets were Kansas (n=697/58, $1202 \%)$, South Dakota ( $\mathrm{n}=185 / 15,1233 \%)$, Mississippi $(\mathrm{n}=749 / 54,1387 \%)$, New Hampshire $(\mathrm{n}=582 / 41,1420 \%)$, and Idaho $(\mathrm{n}=670 / 46,1457 \%)$.

Conclusions: The rise in tweets referencing "Chinese virus" or "China virus," along with the content of these tweets, indicate that knowledge translation may be occurring online and COVID-19 stigma is likely being perpetuated on Twitter.

(J Med Internet Res 2020;22(5):e19301) doi: 10.2196/19301

\section{KEYWORDS}

COVID-19; coronavirus; Twitter; stigma; social media; public health 


\section{Introduction}

Stigma is the deleterious, structural force that devalues those who hold undesirable characteristics [1]. Stigma is a social process that occurs between groups; this process can occur in-person and online [2-6]. Regardless of setting, research has consistently found that stigma is associated with negative health outcomes [2,4,6-9]. For example, HIV-related stigma has pushed the HIV-epidemic underground, fueling ongoing transmission [10], and other disease-related stigmas are associated with negative health outcomes ranging from missed clinical visits to suicidal ideation $[1,6,9]$. There is evidence to show that stigma can become internalized, and internalized stigma can lead to distrust of health professionals, skepticism of public health systems, and an unwillingness to disclose behaviors related to transmission [2,8,9]. Because the coronavirus disease (COVID-19) is infectious, contact tracing is critically important to assessing community spread; thus, it is imperative that individuals trust their public health and health care systems so that they are willing to accept testing and, if diagnosed with COVD-19, report their whereabouts and activities. Therefore, creating and perpetuating stigma related to COVID-19 could be detrimental to public health efforts that require potentially stigmatized individuals to engage with their health systems.

On March 16, 2020, the president of the United States referred to the novel coronavirus as the "Chinese virus" on Twitter. He tweeted "The United States will be powerfully supporting those industries... that are particularly affected by the Chinese Virus..." After this presidential reference, a dialogue emerged examining if the phrase "Chinese virus" was xenophobic and stigmatizing, considering the availability of alternative scientific names such as coronavirus or COVID-19. Since stigma is created and perpetuated by society through social interaction and public commentary (eg, use of the term "Chinese virus" instead of scientific terms on Twitter), and stigma is reinforced by those in power (eg, use of the term "Chinese virus" by the US president), we hypothesized that there would be an increase in the frequency of the phrases "Chinese virus" and "China virus" on Twitter, comparing the prevalence of these phrases before and after the presidential reference.

\section{Methods}

\section{Twitter}

Twitter is an online social media platform where users send and receive short posts (maximum 280 characters) called tweets. Twitter currently has 152 million daily users, who produce about 500 million daily tweets [11].

\section{Data, Tweets}

We downloaded tweets from all 50 US states, using the Sysomos software (Sysomos, Inc). We extracted tweets that mentioned
"Chinese virus" or "China virus" but did not contain "COVID-19" or "coronavirus." The list of keywords referencing the "Chinese virus" are "Chinesevirus," "Chinese virus," "Chinavirus," "China virus," "\#ChineseVirus19," "\#Chinesevirus," "\#ChineseVirusCorona," and "\#Chinavirus." We excluded tweets containing the keywords "coronavirus," "corona virus," "COVID-19," "COVID19," "\#COVID2019," and "\#corona." By excluding tweets that contained both "Chinese virus" and "coronavirus," we collated a sample of tweets that represented the intent of using "Chinese virus" in place of a scientific alternative, likely indicating deliberate stigmatization. We imputed the location of tweets based on Twitter users' self-reported state of residence. Tweets posted between March 9 and March 15, 2020 (preperiod), were compared with tweets posted between March 19 and March 25, 2020 (postperiod). Original tweets and quote tweets (adding comments to an existing tweet) were included but not retweets (reposting of an existing tweet). Our final sample ( $\mathrm{N}=193,862)$ contained all tweets posted in the pre- and postperiods by US-based Twitter users that exclusively mentioned a derivative of "Chinese virus." Data extraction was conducted on April 10, 2020. Ethical approval was provided by the University of Alabama at Birmingham Institutional Review Board (IRB-\#300005071).

\section{Analysis}

We used Stata 16 (StataCorp) to analyze our Twitter data and Python software (Python Software Foundation) to plot our state-level gradient heat map.

\section{Results}

A total of 16,535 "Chinese virus" or "China virus" tweets were identified in the preperiod, and 177,327 tweets were identified in the postperiod, illustrating a $972.43 \%(n=160,792 / 16,535)$ increase. Comparatively, the number of tweets referencing COVID-19 in the preperiod and postperiod remained steady, at about 4.9 million tweets per period. A total of 13,569 (82.06\%) of the preperiod and $145,521(82.06 \%)$ of the postperiod tweets were associated with a Twitter user's self-reported US state. Figure 1 is a heat map illustrating the state-by-state increases of tweets referencing "Chinese virus" or "China virus." The darker the shade, the greater the increase. All 50 US states witnessed an increase in the number of tweets exclusively mentioning "Chinese virus" or "China virus" rather than COVID-19 or coronavirus. The 5 US states with the highest number of postperiod "Chinese virus" tweets were Pennsylvania, New York, Florida, Texas, and California. The 5 US states with the largest increase in pre- to postperiod "Chinese virus" tweets were Kansas, South Dakota, Mississippi, New Hampshire, and Idaho. 
Figure 1. Heat map of increases in tweets referencing "Chinese virus" or "China virus" across the United States.

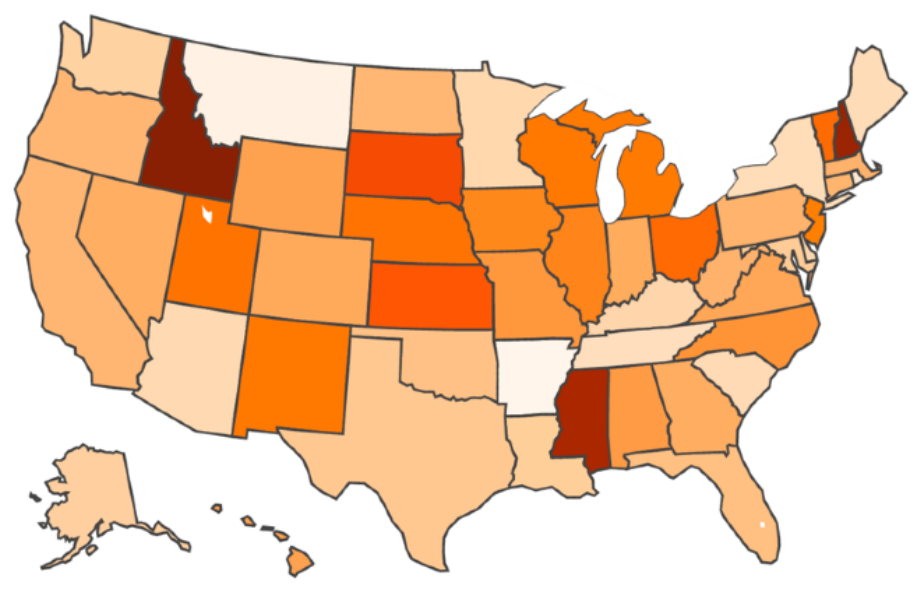

Tweet increase (\%)

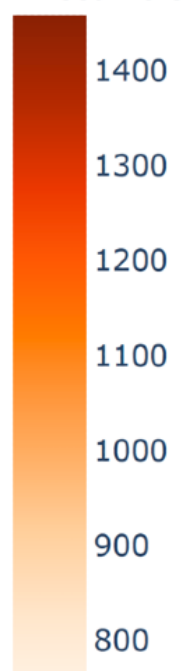

In Table 1, we present US state-level results of tweets referencing "Chinese virus" or "China virus." On average, at the state level, 271 such tweets were found in the preperiod and 2910 in the postperiod, indicating a ten-fold increase, similar to what we found at the national level. We also calculated the percentage increase and the prevalence increase. The percentage increase measures the percentage of all COVID-19 related tweets that mentioned "China virus" or "Chinese virus" exclusively. To account for variations in population size, prevalence of "Chinese virus" tweets per 10,000 people for each US state was calculated using the following formula: $\frac{\text { number of "Chinese virus" tweets }}{\text { state population }} \times 10,000$. State population sizes were taken from the 2019 US Census Bureau estimates [12]. On average, the state-level percentage increase was $997 \%$, with a minimum of $661 \%$ and a maximum of $1447 \%$. Similarly, the prevalence increase mean was $1015 \%$, with a minimum of $734 \%$ and a maximum of $1456 \%$. Large variations were found across US states, with the lowest postperiod prevalence of "Chinese virus" or "China virus" in South Dakota and the highest in Wyoming. The 5 US states with the highest prevalence of "Chinese virus" or "China virus" postperiod tweets were Arizona, New York, Florida, Nevada, and Wyoming. 
Table 1. Tweets referencing the novel coronavirus as "Chinese virus" or "China virus" by state.

\begin{tabular}{|c|c|c|c|c|c|c|c|c|c|c|}
\hline \multirow[t]{2}{*}{ States } & \multicolumn{4}{|l|}{ Preperiod } & \multicolumn{4}{|l|}{ Postperiod } & \multicolumn{2}{|c|}{$\begin{array}{l}\text { Change from pre- to } \\
\text { postperiod }\end{array}$} \\
\hline & $\begin{array}{l}\text { COVID-19 } \\
\text { tweets, } \mathrm{n}\end{array}$ & $\begin{array}{l}\text { "Chinese } \\
\text { virus" } \\
\text { tweets, n }\end{array}$ & $\begin{array}{l}\text { Percentage } \\
\text { of tweets }{ }^{\mathrm{a}} \text {, } \\
(\%)\end{array}$ & $\begin{array}{l}\text { Prevalence } \\
\text { of tweets }^{b}\end{array}$ & $\begin{array}{l}\text { COVID-19 } \\
\text { tweets, } \mathrm{n}\end{array}$ & $\begin{array}{l}\text { "Chinese } \\
\text { virus" } \\
\text { tweets, n }\end{array}$ & $\begin{array}{l}\text { Percentage } \\
\text { of tweets }{ }^{\mathrm{a}} \text {, } \\
(\%)\end{array}$ & $\begin{array}{l}\text { Prevalence } \\
\text { of tweets }^{b}\end{array}$ & $\begin{array}{l}\text { Percentage } \\
\text { increase }^{c} \\
(\%)\end{array}$ & $\begin{array}{l}\text { Prevalence } \\
\text { increase }^{\mathrm{d}} \\
(\%)\end{array}$ \\
\hline AL & 40,588 & 153 & 0.38 & 0.31 & 39,434 & 1749 & 4.44 & 3.57 & 1077 & 1043 \\
\hline $\mathrm{AK}$ & 9251 & 40 & 0.43 & 0.55 & 9597 & 404 & 4.21 & 5.52 & 874 & 910 \\
\hline $\mathrm{AZ}$ & 83,019 & 438 & 0.53 & 0.60 & 89,127 & 4256 & 4.78 & 5.85 & 805 & 872 \\
\hline AR & 21,810 & 109 & 0.50 & 0.36 & 22,741 & 910 & 4.00 & 3.02 & 701 & 735 \\
\hline $\mathrm{CA}$ & 696,645 & 1806 & 0.26 & 0.46 & 685,596 & 19,442 & 2.84 & 4.92 & 994 & 977 \\
\hline $\mathrm{CO}$ & 84,092 & 291 & 0.35 & 0.51 & 85,014 & 3218 & 3.79 & 5.59 & 994 & 1006 \\
\hline CT & 40,304 & 116 & 0.29 & 0.33 & 40,531 & 1253 & 3.09 & 3.51 & 974 & 980 \\
\hline DE & 9789 & 31 & 0.32 & 0.32 & 10,095 & 304 & 3.01 & 3.12 & 851 & 881 \\
\hline FL & 270,723 & 1243 & 0.46 & 0.58 & 294,652 & 13,070 & 4.44 & 6.09 & 866 & 951 \\
\hline GA & 135,543 & 382 & 0.28 & 0.36 & 136,875 & 4192 & 3.06 & 3.95 & 987 & 997 \\
\hline $\mathrm{HI}$ & 15,261 & 53 & 0.35 & 0.37 & 18,237 & 597 & 3.27 & 4.22 & 843 & 1026 \\
\hline ID & 13,810 & 46 & 0.33 & 0.26 & 14,683 & 716 & 4.88 & 4.01 & 1364 & 1457 \\
\hline IL & 176,425 & 410 & 0.23 & 0.32 & 169,849 & 4918 & 2.90 & 3.88 & 1146 & 1100 \\
\hline IN & 58,767 & 192 & 0.33 & 0.29 & 57,218 & 2118 & 3.70 & 3.15 & 1033 & 1003 \\
\hline IA & 27,552 & 71 & 0.26 & 0.23 & 27,917 & 847 & 3.03 & 2.68 & 1077 & 1093 \\
\hline $\mathrm{KS}$ & 24,678 & 58 & 0.24 & 0.20 & 24,694 & 755 & 0.31 & 2.59 & 1201 & 1202 \\
\hline KY & 45,648 & 179 & 0.39 & 0.40 & 45,841 & 1765 & 3.85 & 3.95 & 882 & 886 \\
\hline LA & 51,734 & 151 & 0.29 & 0.32 & 48,623 & 1535 & 3.16 & 3.30 & 982 & 917 \\
\hline $\mathrm{ME}$ & 16,948 & 54 & 0.32 & 0.40 & 17,762 & 520 & 2.93 & 3.87 & 819 & 863 \\
\hline MD & 75,527 & 189 & 0.25 & 0.31 & 76,274 & 1932 & 2.53 & 3.20 & 912 & 922 \\
\hline MA & 138,665 & 295 & 0.21 & 0.43 & 137,279 & 3201 & 2.33 & 4.64 & 996 & 985 \\
\hline MI & 108,514 & 297 & 0.27 & 0.30 & 103,934 & 3623 & 3.49 & 3.63 & 1174 & 1120 \\
\hline $\mathrm{MN}$ & 63,304 & 192 & 0.30 & 0.34 & 65,570 & 1882 & 2.87 & 3.34 & 846 & 880 \\
\hline MS & 19,530 & 54 & 0.28 & 0.18 & 18,771 & 803 & 4.28 & 2.70 & 1447 & 1387 \\
\hline MO & 68,869 & 201 & 0.29 & 0.33 & 71,951 & 2317 & 3.22 & 3.78 & 1003 & 1053 \\
\hline MT & 9365 & 61 & 0.65 & 0.57 & 10,503 & 521 & 4.96 & 4.87 & 662 & 754 \\
\hline $\mathrm{NE}$ & 19,791 & 54 & 0.27 & 0.28 & 18,840 & 670 & 3.56 & 3.46 & 1203 & 1141 \\
\hline $\mathrm{NV}$ & 52,996 & 217 & 0.41 & 0.70 & 53,730 & 2377 & 4.42 & 7.72 & 980 & 995 \\
\hline $\mathrm{NH}$ & 14,260 & 41 & 0.29 & 0.30 & 15,096 & 623 & 4.13 & 4.58 & 1335 & 1420 \\
\hline $\mathrm{NJ}$ & 96,806 & 315 & 0.33 & 0.35 & 100,334 & 3823 & 3.81 & 4.30 & 1071 & 1114 \\
\hline NM & 18,966 & 51 & 0.27 & 0.24 & 20,220 & 627 & 3.10 & 2.99 & 1053 & 1129 \\
\hline NY & 487,901 & 1225 & 0.25 & 0.63 & 484,515 & 11,754 & 2.43 & 6.04 & 866 & 860 \\
\hline $\mathrm{NC}$ & 110,832 & 327 & 0.30 & 0.31 & 115,394 & 3795 & 3.29 & 3.62 & 1015 & 1061 \\
\hline ND & 5649 & 18 & 0.32 & 0.24 & 6148 & 193 & 3.14 & 2.53 & 885 & 972 \\
\hline $\mathrm{OH}$ & 145,371 & 366 & 0.25 & 0.31 & 127,421 & 4613 & 3.62 & 3.95 & 1338 & 1160 \\
\hline $\mathrm{OK}$ & 33,480 & 137 & 0.41 & 0.35 & 33,857 & 1436 & 4.24 & 3.63 & 937 & 948 \\
\hline OR & 64,817 & 185 & 0.29 & 0.44 & 65,972 & 1985 & 3.01 & 4.71 & 954 & 973 \\
\hline PA & 159,712 & 485 & 0.30 & 0.38 & 161,156 & 5249 & 3.26 & 4.10 & 973 & 982 \\
\hline RI & 14,234 & 43 & 0.30 & 0.41 & 14,219 & 385 & 2.71 & 3.63 & 796 & 795 \\
\hline
\end{tabular}




\begin{tabular}{|c|c|c|c|c|c|c|c|c|c|c|}
\hline \multirow[t]{2}{*}{ States } & \multicolumn{4}{|l|}{ Preperiod } & \multicolumn{4}{|l|}{ Postperiod } & \multicolumn{2}{|c|}{$\begin{array}{l}\text { Change from pre- to } \\
\text { postperiod }\end{array}$} \\
\hline & $\begin{array}{l}\text { COVID-19 } \\
\text { tweets, } \mathrm{n}\end{array}$ & $\begin{array}{l}\text { "Chinese } \\
\text { virus" } \\
\text { tweets, n }\end{array}$ & $\begin{array}{l}\text { Percentage } \\
\text { of tweets }{ }^{\mathrm{a}} \text {, } \\
(\%)\end{array}$ & $\begin{array}{l}\text { Prevalence } \\
\text { of tweets }^{b}\end{array}$ & $\begin{array}{l}\text { COVID-19 } \\
\text { tweets, } \mathrm{n}\end{array}$ & $\begin{array}{l}\text { "Chinese } \\
\text { virus" } \\
\text { tweets, n }\end{array}$ & $\begin{array}{l}\text { Percentage } \\
\text { of tweets }{ }^{\mathrm{a}} \text {, } \\
(\%)\end{array}$ & $\begin{array}{l}\text { Prevalence } \\
\text { of tweets }^{b}\end{array}$ & $\begin{array}{l}\text { Percentage } \\
\text { increase }^{c} \\
(\%)\end{array}$ & $\begin{array}{l}\text { Prevalence } \\
\text { increase }^{\mathrm{d}} \\
(\%)\end{array}$ \\
\hline SC & 43,104 & 222 & 0.52 & 0.43 & 46,251 & 2145 & 4.64 & 4.17 & 800 & 866 \\
\hline SD & 6252 & 15 & 0.24 & 0.17 & 6573 & 200 & 3.04 & 2.26 & 1168 & 1233 \\
\hline $\mathrm{TN}$ & 82,478 & 361 & 0.44 & 0.53 & 82,050 & 3431 & 4.18 & 5.02 & 855 & 850 \\
\hline TX & 378,047 & 1442 & 0.38 & 0.50 & 369,006 & 14,861 & 4.03 & 5.13 & 956 & 931 \\
\hline UT & 30,422 & 81 & 0.27 & 0.25 & 28,464 & 1004 & 3.53 & 3.13 & 1225 & 1140 \\
\hline VT & 8625 & 18 & 0.21 & 0.29 & 9527 & 226 & 2.37 & 3.62 & 1037 & 1156 \\
\hline VA & 97,602 & 301 & 0.31 & 0.35 & 104,176 & 3351 & 3.22 & 3.93 & 943 & 1013 \\
\hline WA & 123,025 & 331 & 0.27 & 0.43 & 116,656 & 3316 & 2.84 & 4.35 & 957 & 902 \\
\hline WV & 15,523 & 47 & 0.30 & 0.26 & 15,698 & 509 & 3.24 & 2.84 & 971 & 983 \\
\hline WI & 51,670 & 130 & 0.25 & 0.22 & 52315 & 1593 & 3.05 & 2.74 & 1110 & 1125 \\
\hline WY & 6185 & 45 & 0.73 & 0.78 & 6875 & 507 & 7.37 & 8.76 & 914 & 1027 \\
\hline Mean & 87,482 & 271 & 0.33 & 0.38 & 87,545 & 2910 & 3.57 & 4.08 & 997 & 1015 \\
\hline
\end{tabular}

aPercentage of all COVID-19 related tweets that mentioned "Chinese virus" or "China virus" exclusively.

b Prevalence of "Chinese virus" tweets per 10,000 people was calculated using the following formula: $\frac{\text { number of "chinese virus" tweets }}{\text { state population }} \times 10,000$.

${ }^{\mathrm{c}}$ Percentage of increase was calculated as: $\frac{\text { Postperiod percentage of tweets }- \text { Preperiod percentage of tweets }}{\text { Preperiod percentage of tweets }} \times 100$.

$\mathrm{d}$ Prevalence increase was calculated as: $\frac{\text { Postperiod prevalence of tweets }- \text { Preperiod prevalence of tweets }}{\text { Preperiod prevalence of tweets }} \times 100$.

\section{Discussion}

\section{Principal Result}

We found notable increases in the use of the terms "Chinese virus" and "China virus" on Twitter at both the national and state levels by comparing these tweets (percentage and prevalence) both before and after the March 16, 2020, presidential reference. The following are examples of "Chinese virus" or "China virus" tweets:

- $\quad$ Not parroting MSM's [main stream media's] narrative. It's the \#WuFlu \#ChineseCoronaVirus \#ChinaVirus"

- "\#ChinaVirus \#ChinaLiesPeopleDie"

\section{Limitations}

The pandemic is currently underway, so Twitter data-both in quantity (quantitative) and content (qualitative) — are rapidly shifting. We were unable to screen for automatically generated tweets (bots) within this short report [13,14]. Geographic locations associated with Twitter accounts were self-reported; thus, it is possible that some Twitter users may have moved without updating their state location or may have reported a false state location.

\section{Comparison With Prior Work}

There is a growing body of academic literature that leverages Twitter data to assess trends in population health and public sentiment [15-17]. Chew and Eysenbach [18] conducted a seminal examination of knowledge translation using Twitter data during the H1N1 outbreak; they found the proportion of tweets using "H1N1" increased over time compared to the relative use of "swine flu," suggesting that the media's choice in terminology (shifting from using the term "swine flu" to "H1N1") influenced public uptake. In addition, it is relevant that a recent publication by Logie and Turan [19] presented a narrative on how stigma can hurt the COVID-19 public health response. This short report was developed considering the findings from prior studies.

\section{Future Research}

Future research could evaluate and show that stigma mechanisms work online, validate if Twitter and social media data can be informative to epidemic surveillance and health communication, examine the extent that Twitter and social media data is reliable in informing public health efforts and social science research, and explore how Twitter users view COVID-19 and the COVID-19 public health response (eg, testing, linkage to care).

Additionally, although there is a growing body of research using tweets to examine aspects of the novel coronavirus [20-22], to our knowledge, no studies have included a comprehensive set of search terms, which may include phrases such as "ncov," "covid," "sars-cov," and "rona," in defining their samples. If data extraction is not comprehensive, we run the risk of missing emerging sentiments and terminology, such as referencing the novel coronavirus as the "China virus" or "Chinese virus," and sociobehavioral outcomes related to these trends.

\section{Conclusions}

The rise in tweets citing "Chinese virus" or "China virus" instead of COVID-19 or the novel coronavirus after the presidential reference on Twitter, along with the content of these 
tweets, indicate that knowledge translation may be occurring online and COVID-19 stigma is likely being perpetuated on Twitter. Generally speaking, perpetuating COVID-19-related stigma by using the phrase "Chinese virus" could harm public health efforts related to addressing the pandemic, specifically inciting fear and increasing distrust of public health systems by Chinese and Asian Americans. If these stigmatizing terms persist as malicious synonyms for the novel coronavirus, reparative efforts may be required to restore trust by marginalized communities.

\section{Acknowledgments}

Research reported in this publication was supported by the University of Alabama at Birmingham School of Public Health Back of the Envelope (for RS) and the National Institute of Mental Health of the National Institutes of Health under Award Number $1 \mathrm{~K} 01 \mathrm{MH} 116737$ (for HB). The content is solely the responsibility of the authors and does not necessarily represent the official views of the National Institutes of Health.

\section{Authors' Contributions}

HB conceptualized this study, and RS conducted the data collection and analysis. Both authors contributed to manuscript development and writing.

\section{Conflicts of Interest}

None declared.

\section{References}

1. Goffman E. Stigma: Notes on the Management of Spoiled Identity. Upper Saddle River, NJ: Prentice Hall; 1963.

2. Budhwani H, De P. Perceived stigma in health care settings and the physical and mental health of people of color in the United States. Health Equity 2019;3(1):73-80 [FREE Full text] [doi: 10.1089/heq.2018.0079] [Medline: 30915422]

3. Ho CL, Pan W, Taylor LD. Stigma of HIV testing on online HIV forums: self-stigma and the unspoken. J Psychosoc Nurs Ment Health Serv 2017 Dec 01;55(12):34-43. [doi: 10.3928/02793695-20170905-01] [Medline: 28892555]

4. Karamouzian M, Knight R, Davis WM, Gilbert M, Shoveller J. Stigma associated with sexually transmissible infection testing in an online testing environment: examining the perspectives of youth in Vancouver, Canada. Sex Health 2018;15(1):46. [doi: 10.1071/sh17089]

5. Milin R, Kutcher S, Lewis SP, Walker S, Wei Y, Ferrill N, et al. Impact of a mental health curriculum on knowledge and stigma among high school students: a randomized controlled trial. J Am Acad Child Adolesc Psychiatry 2016 May;55(5):383-391.e1. [doi: 10.1016/j.jaac.2016.02.018] [Medline: 27126852]

6. Pachankis JE, Hatzenbuehler ML, Wang K, Burton CL, Crawford FW, Phelan JC, et al. The burden of stigma on health and well-being: a taxonomy of concealment, course, disruptiveness, aesthetics, origin, and peril across 93 stigmas. Pers Soc Psychol Bull 2018 Apr;44(4):451-474 [FREE Full text] [doi: 10.1177/0146167217741313] [Medline: 29290150]

7. Budenz A, Klassen A, Purtle J, Yom Tov E, Yudell M, Massey P. Mental illness and bipolar disorder on Twitter: implications for stigma and social support. J Ment Health 2020 Apr;29(2):191-199. [doi: 10.1080/09638237.2019.1677878] [Medline: 31694433]

8. Budhwani H, Hearld KR, Milner AN, Charow R, McGlaughlin EM, Rodriguez-Lauzurique M, et al. Transgender women's experiences with stigma, trauma, and attempted suicide in the Dominican Republic. Suicide Life Threat Behav 2018 Dec;48(6):788-796. [doi: 10.1111/sltb.12400] [Medline: 28950402]

9. Turan B, Budhwani H, Fazeli PL, Browning WR, Raper JL, Mugavero MJ, et al. How does stigma affect people living with HIV? The mediating roles of internalized and anticipated HIV stigma in the effects of perceived community stigma on health and psychosocial outcomes. AIDS Behav 2017 Jan;21(1):283-291 [FREE Full text] [doi: 10.1007/s10461-016-1451-5] [Medline: 27272742]

10. Pachankis JE, Hatzenbuehler ML, Hickson F, Weatherburn P, Berg RC, Marcus U, et al. Hidden from health. AIDS 2015;29(10):1239-1246. [doi: 10.1097/qad.0000000000000724]

11. Dai H, Deem MJ, Hao J. Geographic variations in electronic cigarette advertisements on Twitter in the United States. Int J Public Health 2017 May;62(4):479-487. [doi: 10.1007/s00038-016-0906-9] [Medline: 27742923]

12. United States Census Bureau. 2019 Dec. Table 1. Annual Estimates of the Resident Population for the United States, Regions, States, and Puerto Rico: April 1, 2010 to July 1, 2019 (NST-EST2019-01) URL: https://www.census.gov/newsroom/ press-kits/2019/national-state-estimates.html [accessed 2020-04-22]

13. Allem J, Ferrara E. The importance of debiasing social media data to better understand e-cigarette-related attitudes and behaviors. J Med Internet Res 2016 Aug 09;18(8):e219. [doi: 10.2196/jmir.6185] [Medline: 27507563]

14. Allem J, Ferrara E, Uppu SP, Cruz TB, Unger JB. E-cigarette surveillance with social media data: social bots, emerging topics, and trends. JMIR Public Health Surveill 2017 Dec 20;3(4):e98. [doi: 10.2196/publichealth.8641] [Medline: 29263018] 
15. Alessa A, Faezipour M. Flu outbreak prediction using Twitter posts classification and linear regression with historical Centers for Disease Control and Prevention reports: prediction framework study. JMIR Public Health Surveill 2019 Jun 25;5(2):e12383. [doi: 10.2196/12383] [Medline: 31237567]

16. Grajales FJ, Sheps S, Ho K, Novak-Lauscher H, Eysenbach G. Social media: a review and tutorial of applications in medicine and health care. J Med Internet Res 2014 Feb 11;16(2):e13. [doi: 10.2196/jmir.2912] [Medline: 24518354]

17. Ji X, Chun SA, Wei Z, Geller J. Twitter sentiment classification for measuring public health concerns. Soc Netw Anal Min 2015;5(1):13 [FREE Full text] [doi: 10.1007/s13278-015-0253-5] [Medline: 32226558]

18. Chew C, Eysenbach G. Pandemics in the age of Twitter: content analysis of Tweets during the 2009 H1N1 outbreak. PLoS One 2010 Nov 29;5(11):e14118. [doi: 10.1371/journal.pone.0014118] [Medline: 21124761]

19. Logie CH, Turan JM. How do we balance tensions between COVID-19 public health responses and stigma mitigation? learning from HIV research. AIDS Behav 2020 Apr 07:e. [doi: 10.1007/s10461-020-02856-8] [Medline: 32266502]

20. Abd-Alrazaq A, Alhuwail D, Househ M, Hamdi M, Shah Z. Top concerns of Tweeters during the COVID-19 pandemic: infoveillance study. J Med Internet Res 2020 Apr 21;22(4):e19016. [doi: 10.2196/19016] [Medline: 32287039]

21. Kouzy R, Abi Jaoude J, Kraitem A, El Alam MB, Karam B, Adib E, et al. Coronavirus goes viral: quantifying the COVID-19 misinformation epidemic on Twitter. Cureus 2020 Mar 13;12(3):e7255 [FREE Full text] [doi: 10.7759/cureus.7255] [Medline: 32292669]

22. Rosenberg H, Syed S, Rezaie S. The Twitter pandemic: the critical role of Twitter in the dissemination of medical information and misinformation during the COVID-19 pandemic. CJEM 2020 Apr 06:1-4 [FREE Full text] [doi: 10.1017/cem.2020.361] [Medline: 32248871$]$

\section{Abbreviations \\ COVID-19: coronavirus disease}

Edited by G Eysenbach; submitted 12.04.20; peer-reviewed by E Da Silva, JP Allem; comments to author 21.04.20; revised version
received 23.04.20; accepted 26.04.20; published 06.05.20
Please cite as:
Budhwani H, Sun R
Creating COVID-19 Stigma by Referencing the Novel Coronavirus as the "Chinese virus" on Twitter: Quantitative Analysis of Social
Media Data
J Med Internet Res 2020;22(5):e19301
URL: $\underline{\text { http://www.jmir.org/2020/5/e19301/ }}$
doi: $\underline{10.2196 / 19301}$
PMID: $\underline{32343669}$

CHenna Budhwani, Ruoyan Sun. Originally published in the Journal of Medical Internet Research (http://www.jmir.org), 06.05.2020. This is an open-access article distributed under the terms of the Creative Commons Attribution License (https://creativecommons.org/licenses/by/4.0/), which permits unrestricted use, distribution, and reproduction in any medium, provided the original work, first published in the Journal of Medical Internet Research, is properly cited. The complete bibliographic information, a link to the original publication on http://www.jmir.org/, as well as this copyright and license information must be included. 